Volume I Tahun 2021

November 2021
Proceeding The First Muhammadiyah InternasionalPublic Health and Medicine

Conference

\title{
FACTORS RELATED TO REDUCING THE USE OF PLASTIC BAGS IN KABUPATEN BEKASI
}

\author{
${ }^{1}$ Ernyasih, ${ }^{2}$ Isnie Nurajizah Wijayanti, ${ }^{3}$ Triana Srisantyorini, ${ }^{4}$ Andriyani, ${ }^{5}$ Munaya Fauziah \\ ${ }^{1-5}$ Faculty of Public Health, Muhammadiyah University of Jakarta \\ K.H. Ahmad Dahlan St, Cirendeu, Ciputat, South Jakarta, Banten 15419 \\ Email: isnienurajizah99@gmail.com
}

\begin{abstract}
The amount of waste in Indonesia in 2019 will reach 68 million tons and plastic waste is estimated to reach 9.52 million tons or 14 percent of the total existing waste. (Regional Representative Council of the Republic of Indonesia, 2017). In 2018 the total amount of waste in Bekasi Regency reached 152.3 tons per year. The composition of waste from plastic sources ranks first in the type of non-organic waste with a percentage of 9\% (Bekasi Regency Environmental Service, 2018). Many impacts are caused by plastic bags on the environment, human health, and marine life. This study was conducted to determine the factors associated with reducing the use of plastic bags in the Bekasi Regency. The study design used was cross-sectional with primary data distributed through a questionnaire. A sample of 319 people, the retrieval is done by simple random sampling technique. Data analysis used chi square test $(\alpha=0.05)$. Variables related to reducing the use of plastic bags are knowledge ( $p$-value $=0.009$ and $O R=0.465)$ and attitude $(p$-value $=0.038$ and $O R=0.587)$. While the variables that were not related to the reduction in the use of plastic bags were age ( $p$-value $=0.509)$, gender $(p$-value $=0.065)$, education $(p$-value $=0.667)$ and salary $(p$-value $=0.359)$. Factors that influence the reduction in the use of plastic bags in the Bekasi Regency are knowledge and attitudes. It is hoped that there will be an increase in the application of plastic bag costs in government policies regarding the plastic bag diet so that the use of plastic bags in the community can be minimized.
\end{abstract}

Keywords: Plastic bag, Knowledge, and Attitude 
Volume I Tahun 2021

November 2021
E-ISSN: 2808-5361

http://e-journal.fkmumj.ac.id/
Proceeding The First Muhammadiyah InternasionalPublic Health and Medicine Conference

\section{INTRODUCTION}

The issue of global warming and the environment, especially regarding plastic waste, has become one of the most important global problems (Normajatun and Haliq, 2020). Plastic waste is one of the problems experienced by various countries in the world because it is not easily decomposed, but its existence continues to increase every year. Each country has a different amount of plastic waste with various population backgrounds and state conditions (Judge, 2019). Indonesia ranks second after China, followed by the Philippines, Vietnam, Sri Lanka, Thailand, Egypt, Nigeria, Malaysia, and Bangladesh in the list of the top 10 countries that pollute the sea with plastic (Jambeck, R. J, et, al, 2015).

Based on the International Coastal Cleanup Report, ten types of waste that dominate the world's coasts are cigarette butts $(1,863,838)$, plastic drink bottles $(1,578,834)$, plastic bottle caps $(822,227)$, food wrappers $(762,353)$, plastic shopping bags $(520,900)$, plastic caps $(419,380)$, plastic straws and stirrers $(409,087)$, glass drink bottles $(390,468)$, another plastic packaging $(368,655)$ and Styrofoam food containers $(365,584)$ (Ocean Conservancy, 2017). Whereas data from ScienceMag, the amount of global plastic waste production from 1950 to 2015 tends to always show an increase. In 1950, the world's waste production was in the range of 2 million tons per year. Furthermore, in 2015 waste production has reached 381 million tons per year. This figure has increased more than 190 times, with an average increase of 5.8 tons per year (Compass, 2018).

Indonesia has serious problems with waste, the composition of waste generated from human activities is an organic waste as much as $60-70 \%$ and the rest is non-organic waste $30-40 \%$, while the composition of non-organic waste is The second most waste, which is $14 \%$, is plastic waste (Purwaningrum, 2016). The plastic waste that is widely used is from the category of plastic bags or crackle bags. Some, among others, plastic packaging is made of polyethylene, polypropylene, polyvinylchloride (PVC) materials which when burned or heated can produce dioxin, which is a very toxic substance and is a cancer trigger and can reduce a person's immune system. (PPLH, 2007). In addition, the smoke from burning plastic will produce greenhouse gases in the atmosphere which will further aggravate global warming (Adiwijaya, 2008 inAstuti, 2018).

According to data from the Ministry of Environment and Forestry (KLHK) (2019), the trend in the percentage of plastic waste composition in Indonesia continues to increase. In 2014, plastic waste in Indonesia amounted to 14 percent (8.94 million tons) of the composition of existing waste generation (64 million tons). This number increased in 2016, to 16 percent for plastic waste (10.43 million tons) from existing waste generation (65.2 million tons). (Qodriyatun et al., 2019). According to data from the Ministry of Environment and Forestry (KLHK), that the total amount of Indonesian waste in 2019 will reach 68 million tons, and plastic waste is estimated to reach 9.52 million tons or 14 percent of the total waste. (Regional Representative Council of the Republic of Indonesia, 2017). 
E-ISSN: 2808-5361

http://e-journal.fkmumj.ac.id/
Proceeding The First Muhammadiyah InternasionalPublic Health and Medicine Conference

The main ingredients for making PVC are dioctyl phthalate (HUBCAP). DOP is known to be used in the plasticization process. Consumption of DOP in the PVC industry reaches $50-70 \%$ of the total production of plasticizers (additive compounds added to polymers to increase flexibility and workability). Not only effective, but DOP also provides a normal viscosity when applied to PVC. Moreover, the price of DOP is very cheap among about 300 plasticizers developed, because the synthesis process is simple and the raw materials for the petrochemical industry are abundant. (PPLH, 2007).

Much of the plastic bag waste does not go to landfills and only a little is recycled, so a lot of plastic bag waste ends up in waterways, rivers, and finally into the sea. This condition causes many environmental problems (Ekawati, 2016). Plastic that is in a body of water will float or float causing the plastic to become small pieces or flakes this is due to degradation by sunlight (photodegradation), oxidation, and mechanical abrasion, thus forming small particles called microplastics. (Thompson et al., 2009). Microplastics have a size of 0.33 - 5 mm (Lippiatt, Opfer, and Arthur, 2013).

The impact of microplastics on biota in the waters is that it has the potential to cause damage to biota. The entry of microplastics in the body of biota, can damage the function of organs such as the digestive tract, reduce growth rates, inhibit enzyme production, reduce steroid hormone levels, affect reproduction and cause exposure to addictive plastics with greater toxic properties (Wright, Thompson and Galloway, 2013). The danger that will be posed to humans is that if microplastics are in the lumen, they can interact with the blood through an adsorption process that will fill proteins and glycoproteins. It can affect the immune system and intestinal swelling. The very small size of microplastics also allows transportation to other organ tissues (Hollman, Bouwmeester, and Peters, 2013).

The use of plastic that does not meet the requirements will cause various health problems because it can cause cancer triggers and tissue damage in the human body (carcinogenic) (Dewi and Raharjo, 2019). Therefore, the use of plastic in very large quantities will have a significant impact on human health and the environment because plastic is non-biodegradable, it is estimated that it will take 100 to 500 years for plastic to completely decompose in nature. (Karuniastuti, 2013).

According to data from the National Waste Management Information System (SIPSN), in 2019 the waste generation in West Java Province reached 4.9 million tons and the percentage of plastic waste composition was 14\%. (Ministry of Environment and Forestry, 2019). According to data from the National Waste Management Information System (SIPSN), in 2020 the waste generation in West Java Province reached 3.6 million tons and the percentage of plastic waste composition was $16.9 \%$, there was an increase in the percentage of plastic waste composition (Ministry of Environment and Forestry, 2020).

According to the Bekasi Regency Environmental Service (DLH) (2018), it states that the total amount of waste reaches $1,500 \mathrm{~kg}$ per day, in one year the total reaches $152,319,078 \mathrm{~kg}$ or 152.3 tons 
E-ISSN: 2808-5361

http://e-journal.fkmumj.ac.id/
Proceeding The First Muhammadiyah InternasionalPublic Health and Medicine Conference

per year. The composition of waste from plastic sources ranks first in the type of non-organic waste with a percentage of 9\% (Bekasi Regency Environmental Service, 2018). According to data from the National Waste Management Information System (SIPSN), in 2019 the waste generation in Bekasi Regency reached 662.4 tons per year (Ministry of Environment and Forestry, 2019). There was an increase in waste generation in Bekasi Regency in 2020, according to data obtained from the National Waste Management Information System (SIPSN), waste generation in 2020 reached 693.5 tons per year (Ministry of Environment and Forestry, 2020).

In 2017, the United Nations launched the global campaign "The United Nations Environment Program (UNEP)", to urge everyone to eliminate the use of microplastics and single-use plastic bags. The main concern is the accumulation of plastic waste in the oceans and their destructive power on wildlife, and the possible long-term negative effects on the food chain (Kish, 2018).

The condition of the generation of plastic waste that increases every year makes The Ministry of Environment and Forestry implements a policy regarding the plastic bag diet through a circular letter from the Director-General of Waste, Waste and Hazardous Toxic Management Number S.1230/PSLB3PS/2016 concerning Prices and Mechanisms for Application of Paid Plastic Bags. This policy has been piloted in 22 cities in Indonesia (Ministry of Environment and Forestry, 2016).

Responding to the government's policy, the Bekasi Regency Government then made a policy in the form of a regulation The Regent (PERBUP) of Bekasi Regency Number 34 of 2019 concerning Reducing the Use of Plastic Bags. The policy was made to invite the public to no longer depend on plastic bags so that they can protect the area from environmental damage caused by the use of plastic bags.

Knowledge is the result of knowing and this occurs after people have sensed a certain object. Knowledge of cognition is a very important domain in shaping one's actions (overt behavior) (Notoatmodjo, 2007). Presearch Nasution and Harahap (2018), states that there is a significant relationship between knowledge and the use of plastic bags and has a moderate correlation in a positive direction, which means that the fewer knowledge employees have, the more employees will have bad actions in using plastic bags. While research Sumbung (2015) that there is no relationship between knowledge and attitude with the actions of fried food sellers in reducing the use of plastic bags. It is supported by important information that is known by fried food seller about plastic bags that not all types of plastic can be used as a container for food hot.

According to research results Guslaida, Naria, and Santi (2014) showed a significant relationship between work, knowledge, and attitudes with the use of plastic bags at the Firdaus Traditional Market, Medan Tembung District. Knowledge related to the use of plastic bags because good education does not guarantee to have a good attitude as well as attitudes related to the use of plastic bags because a good attitude does not guarantee good concern for the use of plastic bags. 
Environmental factors and behavioral factors are very influential on the degree of public health. Healthy behavior factors are expected to maintain, improve health and protect themselves from the threat of disease, while a healthy environment is expected to create a conducive, pollution-free environment and healthy settlements. Behavior is an attitude that is born as a result of the interaction between humans and the environment so that individual and community behavior can affect environmental conditions and public awareness can influence this (Setyowati and Mulasari, 2013).

Based on these data and the condition of a waste generation that increases every year in Indonesia, as well as the generation of plastic waste in Bekasi Regency which was ranked first in 2018 so that it has an impact on the environment such as contamination of soil and groundwater, the researchers wanted to research "Factors Related to Reducing the Use of Plastic Bags when Shopping in Bekasi Regency".

\section{METHODS}

This research is a quantitative analytical research using a study design cross-sectional and primary data collection using a questionnaire. The sample in this study was 319 people domiciled in Bekasi Regency using simple random sampling. The analysis carried out in this study was univariate analysis to see prevalence and bivariate chi-square analysis $(\alpha=0.05)$, and the calculation of Odds Ratio (OR).

\section{RESULTS AND DISCUSSIONS}

Table 1. Univariate Analysis

\begin{tabular}{llcc}
\hline \multicolumn{1}{c}{ Variable Name } & n & \% \\
\hline 1. & Reducing Use of Plastic Bags & & \\
Using a plastic bag & 216 & 67.7 \\
Don't use plastic bags & 103 & 32.2 \\
2. Age & & \\
25 & 242 & 75.9 \\
$\quad>25$ & 77 & 24.1 \\
3. Gender & 210 & 65.8 \\
Woman & 109 & 34.2 \\
Man & & \\
Education & 9 & 2.8 \\
Low & 310 & 97.2 \\
Tall & & 27.3 \\
Wages & 87 & 72.7 \\
Minimum wage 4,791,843 & 232 & 21.0 \\
No UMR <4.791.843 & & 79.0 \\
Not good & 67 & 39.8 \\
Well & 252 & 60.2 \\
Attitude & & \\
Negative & 127 & \\
Positive & 192 & \\
\hline
\end{tabular}


E-ISSN: 2808-5361

http://e-journal.fkmumj.ac.id/
Proceeding The First Muhammadiyah InternasionalPublic Health and Medicine Conference

In this study, based on the data in the table, it can be seen the distribution of the reduction in the use of plastic bags when shopping from a total of 319 respondents there are 216 people $(67.7 \%)$ still using plastic bags, while 103 people (32.3\%) are not using plastic bags. Based on the data in the table, it can be seen that the age distribution of 319 respondents, the majority of respondents aged 25 years is $242(75.9 \%)$, while respondents aged $>25$ years are 77 (24.1\%). The value of the mode on this variable is 21. Based on the data in the table, it was found that the distribution of sex in 319 respondents in Bekasi Regency. The number of respondents who are female is as many as 210 people $(65.8 \%)$ while male sex as many as 109 people (34.2\%).

Based on the data in the table, the distribution of education levels in 319 respondents in the Bekasi Regency was obtained. The most recent education of respondents was found with high schoolcollege education graduates as many as 310 people (97.2\%) while respondents who graduated from elementary-junior high school education were 9 people (2.8\%). Based on the data in the table, the distribution of salaries in 319 respondents in the Bekasi Regency is obtained. The majority of respondents who received no UMR salary were 232 people (72.7\%) while respondents who received UMR salary were 87 people (27.3\%). Based on the data in the table, the distribution of knowledge was found in 319 respondents in Bekasi Regency. The proportion of respondents who have good knowledge is as many as 252 people (79\%) while the knowledge is not good as many as 67 people (21\%).

Based on the data in the table, The distribution of attitudes was found in 319 respondents in Bekasi Regency. The proportion of respondents who have a positive attitude is 192 people $(60.2 \%)$ while a negative attitude is 127 people (39.8\%).

The results of the analysis of the relationship between age and the reduction in the use of plastic bags at the time of shopping showed that respondents aged 25 years did not use plastic bags more as many as 81 people (33.5\%) compared to respondents aged $>25$ years as many as 22 people $(28.6 \%)$. The results of the statistical test using Chi-Square with the Continuity Correction test showed a p-value of 0.509 ( -value > 0.05), which means that there is no significant relationship between age and the reduction in the use of plastic bags.

The results of the analysis of the relationship between gender and reducing the use of plastic bags at the time of shopping showed that more female respondents did not use plastic bags as many as 60 people (28.6\%) compared to 43 male respondents (39.4\%). The results of the statistical test using Chi-Square with the Continuity Correction test showed a p-value of 0.065 (p-value > 0.05), which means that there is no significant relationship between gender and the reduction in the use of plastic bags.

The results of the analysis of the relationship between education and reducing the use of plastic bags when shopping shows that respondents with a low level of education there are as many as 4 people (44.4\%) do not use plastic bags and respondents with a high level of education as many as 99 people 
E-ISSN: 2808-5361

http://e-journal.fkmumj.ac.id/
Proceeding The First Muhammadiyah InternasionalPublic Health and Medicine Conference

(31.9\%) do not use plastic bags. The results of the statistical test using Chi-Square with the Continuity Correction test showed a p-value of 0.667 ( $\mathrm{p}$-value > 0.05), which means that there is no significant relationship between education and the reduction in the use of plastic bags.

The results of the analysis of the relationship between salary and reducing the use of plastic bags the time of shopping showed that respondents with UMR salaries were 32 people (36.8\%) did not use plastic bags and respondents with salaries not UMR as many as 71 people (30.6\%) did not use plastic bags. The results of the statistical test using Chi-Square with the Continuity Correction test showed a p-value of 0.359 ( $\mathrm{p}$-value > 0.05), which means that there is no significant relationship between salary and reduction in the use of plastic bags.

The results of the analysis of the relationship between knowledge and reduced bag use plastic bags when shopping shows that respondents with poor knowledge are 31 people (46.3\%) and respondents with good knowledge are 72 people (28.6\%) do not use plastic bags. The results of the statistical test using Chi-Square with the Continuity Correction test showed a p-value of 0.009 (p-value $<0.05$ ), which means that there is a significant relationship between knowledge and reducing the use of plastic bags. From the results of the analysis, the OR (odds ratio) value of 0.465 (95\% CI 0.267 0.807 ) means that respondents with poor knowledge have 0.465 times the opportunity to use plastic bags compared to respondents with good knowledge.

The results of the analysis of the relationship between attitudes and reducing the use of plastic bags at the time of shopping showed that respondents with a negative attitude were 50 people $(39.4 \%)$ did not use plastic bags and respondents with positive attitudes were 53 people (27.6\%) did not use plastic bags. The results of the statistical test using Chi-Square with the Continuity Correction test showed a p-value of 0.038 ( $\mathrm{p}$-value $<0.05$ ), which means that there is a significant relationship between attitudes and the reduction in the use of plastic bags. From the results of the analysis, the OR (odds ratio) value of 0.587 (95\% CI 0.365-0.945) means that respondents with a negative attitude have 0.587 times the opportunity to use plastic bags compared to positive attitudes.

The results of the analysis of the relationship between age and the reduction in the use of plastic bags at the time of shopping showed that respondents aged 25 years did not use plastic bags more as many as 81 people $(33.5 \%)$ compared to respondents aged $>25$ years as many as 22 people $(28.6 \%)$. The results of the statistical test using Chi-Square with the Continuity Correction test showed a p-value of 0.509 ( $\mathrm{p}$-value > 0.05), which means that there is no significant relationship between age and the reduction in the use of plastic bags.

As a person's age increases, there will be changes so that mental thinking becomes more mature and mature (Mubarak, et al, 2007). In this study, the number of respondents aged 25 was 242 people, while respondents aged $>25$ were 77 people. The researcher assumes by looking at the answers in the questionnaire that respondents with the age variable already know information about policies to reduce 
E-ISSN: 2808-5361

http://e-journal.fkmumj.ac.id/
Proceeding The First Muhammadiyah InternasionalPublic Health and Medicine Conference

the use of plastic bags. However, some do not know, but some already know that they remain indifferent or do not apply it.

The results of this study are in line with research conducted by Munawaroh and Suryani and 2019 with seblak traders respondents. The results of the study stated that the p-value was 0.543 (p-value $>0.05$ ) meaning that there was no relationship between age and the behavior of using styrofoam containers on seblak traders in Umbulharjo and Gondokusuman sub-districts, Yogyakarta.

Some studies are not in line with the results of this study. Research conducted bySaputri, Fauzan, and Maheasy (2020) the results of the analysis obtained p $0.000(\alpha<0.05)$ meaning that there is a relationship between age and $3 \mathrm{R}$ efforts in minimizing plastic waste.

The results of the analysis of the relationship between gender and the reduction in the use of plastic bags when shopping showed that 60 female respondents (28.6\%) did not use plastic bags compared to 43 male respondents (39.4\%). The results of the statistical test using Chi-Square with the Continuity Correction test showed a p-value of 0.065 ( -value > 0.05), which means that there is no significant relationship between gender and the reduction in the use of plastic bags.

Differences in the behavior of men and women can be seen in the way they dress and do their daily work. Men behave based on rational considerations or reason, while women are based on emotional considerations or feelings(Hartono, 2016). Based on observations in the field, 150 female respondents still use plastic bags. Researchers assume that women who still use plastic bags may forget to bring their cloth shopping bags from home. For male respondents, they are more likely to choose plastic bags because they are lazy to carry shopping bags made of cloth.

Research conducted by Wagners of 2017 stated that there was a decrease in men's participation in environmental actions because they carried shopping bags made of cloth that were considered feminine.

The results of this study are in line with the research conducted by Munawaroh and Suryani in 2019 the calculation results obtained $p$-value $=0.252$ (p-value $>0.05)$ which means that there is no relationship between gender and the behavior of using styrofoam containers on seblak traders in Umbulharjo and Gondokusuman districts, Yogyakarta.

Some studies are not in line with the results of this study. Research conducted by Utami, Firdaus, and Martha (2020) stated that the significant value of gender was 0.043 (p-value < 0.05), meaning that gender had an influence on public awareness of the environment in the program without plastic bags.

The results of the analysis of the relationship between education and reducing the use of plastic bags when shopping showed that respondents with a low level of education were 4 people (44.4\%) who did not use plastic bags and respondents with a higher education level were 99 people (31.9\%) did not. use a plastic bag. The results of the statistical test using Chi-Square with the Continuity Correction test 
E-ISSN: 2808-5361

http://e-journal.fkmumj.ac.id/
Proceeding The First Muhammadiyah InternasionalPublic Health and Medicine Conference

showed a p-value of 0.667 ( $\mathrm{p}$-value > 0.05), which means that there is no significant relationship between education and the reduction in the use of plastic bags.

Education is given to someone so that they understand something. The higher a person's education, the easier it is to receive information and the more knowledge he has (Mubarak, et al, 2007). Education is seen as the first step in achieving a reduction in the use of plastic bags or increasing recycling. Education is designed to provide customized information and to maintain regular dissemination of information to encourage and support resource reduction, for example: using cloth shopping bags so that they can be reused (Wagner, 2017).

Based on the results of field observations, the people of Bekasi Regency at the level of higher education, namely the last education of SMA and College still use plastic bags. The higher the level of education, there is no relationship between reducing the use of plastic bags. This is thought to happen because people are still not aware of the dangers posed by plastic bags.

The results of this study are in line with research conducted by Permatasari 2019 shows that the significant value is 0.403 ( $\mathrm{p}$-value > 0.05 ) meaning that there is no relationship between education and waste bank management behavior.

Some studies are not in line with the results of this study. Research conducted by Saputri, Fauzan, and Maheasy (2020) the results obtained a p-value of $0.001<0.05$, meaning that there is a relationship between education and $3 \mathrm{R}$ efforts in minimizing plastic waste.

The results of the analysis of the relationship between salary and reducing the use of plastic bags when shopping shows that respondents with UMR salaries as many as 32 people (36.8\%) do not use plastic bags and respondents with salaries not UMR as many as 71 people (30.6\%) do not use plastic bags. plastic bags. The results of the statistical test using Chi-Square with the Continuity Correction test showed a p-value of $0.359 \mathrm{p}$-values> 0.05 ), which means that there is no significant relationship between salary and reduction in the use of plastic bags.

In research conducted by (Thomas et al., 2019)stated that the behavior of higher-income groups may be less affected by costs than lower-income groups (the cost of a plastic bag is five pence). However, in this study, the UMR and non-UMR salaries still use plastic bags because according to government policy regarding the plastic bag diet, the price of a plastic bag is Rp. 200.00. So that people with UMR and not UMR salaries are less affected by the price of their plastic bags.

The results of this study are in line with research conducted by Rida, Prihatini, and Firmansyah in 2018 the results of zone three research based on the results of the chi-square test between income and waste facilities for the people along the Pekapuran river, it can be stated that there is no significant relationship between income and waste facilities with a probability of 0.184 (p-value > 0.05 ).

Some studies are not in line with the results of this study. Research conducted by Jayanti, Christiawan, and Sarmita (2017) found that the income level variable has a positive and significant 
influence on the form of inorganic waste management. This is evidenced by a significance value of 0.000 ( $\mathrm{p}$-value < 0.05 ), and at value of 0.565 .

The results of the analysis of the relationship between knowledge and reducing the use of plastic bags during the time of shopping showed that respondents with poor knowledge were 31 people (46.3\%) and respondents with good knowledge were 72 people (28.6\%) who did not use plastic bags. The results of the statistical test using Chi-Square with the Continuity Correction test showed a p-value of 0.009 (p-value $<0.05$ ), which means that there is a significant relationship between knowledge and the reduction in the use of plastic bags.

Knowledge can be interpreted as remembering, understanding, and applying a material that has been studied previously (Notoatmodjo, 2007). In this study, from 319 respondents 252 respondents already had good knowledge and 67 respondents had poor knowledge.

The results of this study are in line with the research conducted by Nasution, and Harahap (2018)it was found that the results of statistical tests obtained $\mathrm{p}=0.034$ and $\mathrm{r}=0.378$, it can be concluded that there is a significant relationship between knowledge and the use of plastic bags and has a moderate correlation with a positive direction. Another researcher stated that there was a significant relationship between knowledge ( $\mathrm{p}=0.034)$ on the use of plastic bags in the Firdaus Traditional Market, Medan Tembung District, which was carried out byGuslaida, Naria, and Santi in 2014.

Some studies are not in line with the results of this study. Research conducted bySumbung (2015)with fried food sellers. The results of the study stated that there was no relationship between knowledge and respondents' actions in reducing the use of plastic bags. The discussion found that 50\% of respondents have good knowledge but $55.7 \%$ of respondents have bad actions.

Table 2. Bivariate Analysis

\begin{tabular}{|c|c|c|c|c|c|c|c|c|c|}
\hline & \multirow{3}{*}{ Variable } & \multicolumn{4}{|c|}{ Reducing Use of Plastic Bags } & & & \multirow{3}{*}{ OR $(95 \%$ CI $)$} & \multirow{3}{*}{ P-value } \\
\hline & & \multicolumn{2}{|c|}{$\begin{array}{c}\text { Using Plastic } \\
\text { Bags }\end{array}$} & \multicolumn{2}{|c|}{$\begin{array}{c}\text { Not Using } \\
\text { Plastic Bags }\end{array}$} & \multicolumn{2}{|c|}{ Total } & & \\
\hline & & $\mathbf{n}$ & $\%$ & $\mathbf{n}$ & $\%$ & $\mathbf{n}$ & $\%$ & & \\
\hline \multirow[t]{3}{*}{1.} & Age & & & & & & & & \\
\hline & 25 & 161 & 66.5 & 81 & 33.5 & 242 & 100 & & \multirow{2}{*}{0.509} \\
\hline & $>25$ & 55 & 71.4 & 22 & 28.6 & 77 & 100 & & \\
\hline \multirow[t]{3}{*}{2.} & Gender & & & & & & & & \\
\hline & Woman & 150 & 71.4 & 60 & 28.6 & 210 & 100 & & \multirow{2}{*}{0.065} \\
\hline & Man & 66 & 60.6 & 43 & 39.4 & 109 & 100 & & \\
\hline \multirow[t]{3}{*}{3.} & Education & & & & & & & & \\
\hline & Low & 5 & 55.6 & 4 & 44.4 & 9 & 100 & & \multirow{2}{*}{0.667} \\
\hline & Tall & 211 & 68.1 & 99 & 31.9 & 310 & 100 & & \\
\hline \multirow[t]{2}{*}{4.} & Wages & & & & & & & & \\
\hline & $\begin{array}{l}\text { Minimum wage } \\
4,791,843\end{array}$ & 55 & 63.2 & 32 & 36.8 & 87 & 100 & & 0.359 \\
\hline
\end{tabular}


Volume I Tahun 2021 November 2021
E-ISSN: 2808-5361 http://e-journal.fkmumj.ac.id/
Proceeding The First Muhammadiyah InternasionalPublic Health and Medicine Conference

\begin{tabular}{|c|c|c|c|c|c|c|c|c|c|}
\hline & $\begin{array}{l}\text { No } \quad \text { UMR } \\
<4.791 .843\end{array}$ & 161 & 69.4 & 71 & 30.6 & 232 & 100 & & \\
\hline 5. & Knowledge & & & & & & & & \\
\hline & Not good & 36 & 53.7 & 31 & 46.3 & 67 & 100 & \multirow{3}{*}{$\begin{array}{c}0.465(0.267- \\
0.807)\end{array}$} & \multirow{2}{*}{0.009} \\
\hline & Well & 180 & 71.4 & 72 & 28.6 & 252 & 100 & & \\
\hline 6. & Attitude & & & & & & & & \\
\hline & Negative & 77 & 60.6 & 50 & 39.4 & 127 & 100 & \multirow{2}{*}{$\begin{array}{c}0.587(0.365- \\
0.945)\end{array}$} & \multirow{2}{*}{0.038} \\
\hline & positive & 139 & 72.4 & 53 & 27.6 & 192 & 100 & & \\
\hline
\end{tabular}

The results of the analysis of the relationship between attitudes and reducing the use of plastic bags when shopping shows that respondents with a negative attitude there are 50 people (39.4\%) still using plastic bags and respondents with a positive attitude as many as 53 people (27.6\%) do not use plastic bags. The results of the statistical test using Chi-Square with the Continuity Correction test showed a p-value of 0.038 ( $\mathrm{p}$-value $<0.05$ ), which means that there is a significant relationship between attitudes and reducing the use of plastic bags.

Attitudes in everyday life are emotional reactions to social stimuli (Mubarak, et al, 2007). Human habits continue to be repeated in the same way as the habits of respondents who apply when shopping using plastic bags, asking for additional plastic bags as needed and using single-use plastic bags (Sarwono, 2014). In this study, from 319 respondents, 192 respondents had positive characteristics, while 127 respondents had negative characteristics.

The results of this study are in line with research conducted by Damanik (2012) it was found that there was a relationship between respondents' attitudes and actions in using recycled black crackle plastic as ready-to-eat food containers $(\mathrm{p}=0.0001)$. Other researchers stated that there was a significant relationship between attitudes and the use of plastic bags and had a moderate correlation with the positive direction $(\mathrm{p}=0.018)$ conducted by Nasution and Harahap in 2019.

Some studies are not in line with the results of this study. Research conducted by (Simanjuntak, 2010) with food seller respondents. These results have not shown a significant relationship between attitudes and actions of food sellers in the North Sumatra university campus.

\section{CONCLUSION AND SUGGESTIONS}

Based on the results of research conducted on 319 respondents, the researchers concluded that the factors related to reducing the use of plastic bags, namely Reducing the use of plastic bags when shopping there were 103 people (32.3\%), based on the age factor with the majority of the age group 25 In the year there were 242 people (75.9\%), based on gender, most of them were female, 210 people (65.8\%), based on education factor, dominated by higher education level, there were 310 people (97.2\%), based on salary factor. with the majority of salaries, not UMR there are as many as 232 people 
Volume I Tahun 2021

November 2021
E-ISSN: 2808-5361

http://e-journal.fkmumj.ac.id/
Proceeding The First Muhammadiyah InternasionalPublic Health and Medicine Conference

(72.7\%), based on the knowledge factor the majority have good knowledge there are 252 people (79\%), and based on the attitude factor who have a positive attitude there are 192 people $(60.2 \%)$.

knowledge $(\mathrm{p}$ value $=0.009$ and $\mathrm{OR}=0.465)$ and attitude $(\mathrm{p}$ value $=0.038$ and $\mathrm{OR}=0.587)$. While the variables that were not related to the reduction in the use of plastic bags were age ( $\mathrm{p}$ value $=$ $0.509)$, gender $(\mathrm{p}$ value $=0.065)$, education $(\mathrm{p}$ value $=0.667)$ and salary $(\mathrm{p}$ value $=0.359)$.

It is expected to be input in taking action to reduce the use of plastic bags in the Bekasi Regency. Such as the increase in the application of plastic bag fees in government policies regarding the plastic bag diet so that the use of plastic bags by the community can be minimized.

Holding campaign activities, counseling, and making advertisements in other information media to increase people's knowledge and attitudes towards environmental care so that people slowly reduce the use of plastic bags and start not using plastic bags every time they shop so that the use of plastic bags is reduced and environmental pollution caused by plastic bags can be minimized.

\section{REFERENCES}

Ali, Lukman, dan Chayadi, H. W. M. (2019) 'Pemanfaatan Limbah Anorganik sebagai Pemberdayaan Bahan Bakar Minyak (Pemanik BBM)', 2(1), pp. 34-38.

Anam, Faisal, Sakhatmo, Tri, H. (2019) Yuk, Kurangi Pemakaian Plastik. Solo: PT Tiga Serangkai Pustaka Mandiri.

Astuti, A. D. (2018) 'Penerapan Kantong Plastik Berbayar Sebagai Upaya Mereduksi Penggunaan Kantong Plastik', Jurnal Litbang: Media Informasi Penelitian, Pengembangan dan IPTEK, 12(1), pp. 32-40. doi: 10.33658/jl.v12i1.50.

Chandra, Y., Setiawan, D. and Kusmanto (2009) 'Potensi Kulit Jeruk sebagai Bahan Pengurai pada Proses Pengolahan Limbah Kantong Plastik'.

Damanik, E. (2012) 'Perilaku Konsumen Dalam Penggunaan Plastik Kresek Hitam Daur Ulang Sebagai Wadah Makanan Siap Santap Di Pusat Pasar Tavip Binjai', Precure, 1(April), pp. 8-14.

Departemen Kesehatan RI (2009) Kategori Umur.

Dewan Perwakilan Daerah Republik Indonesia (2017) 'Keputusan Dewan Perwakilan Daerah Republik Indonesia tentang Hasil Pengawasan Dewan Perwakilan Daerah Republik Indonesia atas Pelaksanaan Undang-Undang Republik Indonesia Nomor 18 Tahun 2008', CosmoGov, 1(1), p. 48. doi: 10.24198/cosmogov.v1i1.11860.

Dewi, Y. and Raharjo, T. (2019) 'Aspek Hukum Bahaya Plastik Terhadap Kesehatan dan Lingkungan

Serta Solusinya', Kosmik Hukum, 19(1). doi: 10.30595/kosmikhukum.v19i1.4082.

Dinas Lingkungan Hidup Kabupaten Bekasi (2018) Rekapitulasi Penimbangan Sampah Tahun 2018.

Divisi Penulisan dan Multimedia Move Indonesia Divisi Penerbitan dan Dokumentasi Pusat Pendidikan Lingkungan Hidup (PPLH) Seloliman (2007) 'Bahaya Bahan Plastik’, pp. 1-36. 
Volume I Tahun 2021

November 2021
E-ISSN: 2808-5361

http://e-journal.fkmumj.ac.id/
Proceeding The First Muhammadiyah InternasionalPublic Health and Medicine Conference

Ekawati, S. (2016) 'Mengkritisi Kebijakan Penanganan Kantong Plastik di Indonesia', 10, pp. 1-4.

Guslaida, M., Naria, E. and Santi, D. N. (2014) 'Hubungan Karakteristik Pengetahuan dan Sikap pada Pembeli dan Pedagang dengan Penggunaan Kantong Plastik di Pasar Tradisional Firdaus Kecamatan Medan Tembung Tahun 2014'.

Hakim, M. Z. (2019) ‘Pengelolaan dan Pengendalian Sampah Plastik Berwawasan Lingkungan', 27(2), pp. 111-121.

Hamidah, L. (2018) Teknologi Pengolahan Sampah Skala Besar: Ecobrick, Minyak Pirolis, Batako, dan Paving Block, dan Sampuran Aspal. Yogyakarta: Hijaz Pustaka Mandiri.

Hartono, D. (2016) 'Psikologi Keperwatan'.

Hollman, P. C. H., Bouwmeester, H., and Peters, R. J. B. (2013) 'Microplastics in The Aquatic Food Chain; Sources, Measurement, Occurrence and Potential Health Risks', p. 32.

Isabella, S. et al. (2020) 'Analisis Faktor yang Berhubungan dengan Upaya 3R (Reduce, Reuse, Recycle) pada Ibu-Ibu di Jalan Jati RT 03 RW 08 Kelurahan Panarung Kecamatan Pahandut Kota Palangka Raya Tahun 2020', 34.

Jambeck, R. J, et, al (2015) 'Plastic waste inputs from land into the ocean', Science, (September 2014), pp. $1655-1734$.

Jayanti, K. R., Christiawan, P. I. and Sarmita, M. (2017) 'Pengaruh Tingkat Pendidikan dan Tingkat Pendapatan terhadap Bentuk Pengelolaan Sampah Anorganik Rumah Tangga di Desa Alasangker', 5(2).

Karuniastuti, N. (2013) 'Bahaya Plastik terhadap Kesehatan dan Lingkungan’, 03(1).

Kementerian Lingkungan Hidup dan Kehutanan (2016) 'Surat Edaran KLHK tentang Harga dan Mekanisme Penerapan Kantong Plastik Berbayar', p. 1.

Kementerian Lingkungan Hidup dan Kehutanan (2019) Timbulan Sampah dan Komposisi Sampah.

Kementerian Lingkungan Hidup dan Kehutanan (2020) Timbulan Sampah dan Komposisi Sampah.

Keputusan Gubernur Jawa Barat Nomor: 561/Kep.774-Yanbangsos/2020 (2020) Upah Minimum Kabupaten/Kota di Daerah Provinsi Jawa Barat Tahun 2021.

Kish, R. J. (2018) 'Using Legislation To Reduce One-Time Plastic Bag Usage', Economic Affairs, 38(2), pp. 224-239. doi: 10.1111/ecaf.12287.

Kompas (2018) Sampah Plastik Dunia dalam Angka.

Koswara, S. (2006) 'Bahaya di Balik Kemasan Plastik', Pernah dimuat di FEMINA, 2014, 6(2), pp. 13.

Lippiatt, S., Opfer, S. and Arthur, C. (2013) 'Marine Debris Monitoring and Assessment', NOAA Technical Memorandum, (NOS-OR\&R-46), p. 88.

Mubarak, Iqbal Wahid, Chayatin, Nurul, Rozikin, Khoirul, dan S. (2007) Promosi Kesehatan Sebuah Pengantar Proses Belajar Mengajar dalam Pendidikan. Yogyakarta: Graha Ilmu. 
Volume I Tahun 2021

November 2021
E-ISSN: 2808-5361

http://e-journal.fkmumj.ac.id/
Proceeding The First Muhammadiyah InternasionalPublic Health and Medicine Conference

Munawaroh, I. and Suryani, D. (2019) 'Faktor-Faktor Yang Berhubungan Dengan Perilaku Penggunaan

Wadah Styrofoam Pada Pedagang Seblak Di Kecamatan Umbulharjo Dan Gondokusuman Yogyakarta Tahun 2019', pp. 1-15.

Nasution, Hidayah Nurul dan Harahap, W. Y. (2018) 'Hubungan Pengetahuan Karyawan STIKes Aufa Royhan dengan Penggunaan Kantong Plastik', Jurnal Kesehatan Ilmiah Indonesia, 3(2), pp. $22-28$.

Nasution, H. N. and Harahap, W. Y. (2019) 'Hubungan Sikap Karyawan STIKes Aufa Royhan dengan Penggunaan Kantong Plastik', 8(1), pp. 26-30.

Nathania, B. E. and Purnama, H. G. I. (2020) 'Pengetahuan, Sikap dan Perilaku Penjual terhadap Pelarangan Penggunaan Kantong Belanja Plastik Sekali Pakai di Pasar Tradisional Badung Kota Denpasar', 7.

Normajatun dan Haliq, A. (2020) 'Kebijakan Pemerintah Tentang Pengurangan Penggunaan Kantong Plastik di Pasar Tradisional Kota Banjarmasin', 5(2), pp. 55-63.

Notoatmodjo, S. (2007) Promosi Kesehatan dan Ilmu Perilaku. Jakarta: Rineka Cipta.

Notoatmodjo, S. (2010) Metodologi Penelitian Kesehatan. Jakarta: PT Rineka Cipta.

Ocean Conservancy (2017) 'Together for our Ocean - International Coastal Cleanup 2017 Report', p. 28.

Permatasari, R. I. (2019) 'Hubungan Antara Sikap dan Tingkat Pendidikan Ibu Rumah Tangga Dengan Perilaku Pengelolaan Bank Sampah Di Rw 02 Kelurahan Winongo Kota Madiun Tahun 2018', Journal of Chemical Information and Modeling, 53(9), pp. 1689-1699.

Priyoto (2014) Teori Sikap dan Perilaku dalam Kesehatan. Yogyakarta: Nuha Medika.

Purwaningrum, P. (2016) ‘Upaya Mengurangi Timbulan Sampah Plastik Di Lingkungan’, Indonesian Journal of Urban and Environmental Technology, 8(2), p. 141. doi: 10.25105/urbanenvirotech.v8i2.1421.

Qodriyatun, S. N. et al. (2019) Sampah Plastik Dan Implikasi Kebijakan Pembatasan Plastik Sekali Pakai Terhadap Industri Dan Masyarakat, Berkas.Dpr.Go.Id.

Ridha, H., Prihatini, N. S. and Firmansyah, M. (2018) 'Pola Pengelolaan Sampah Rumah Tangga di Sepanjang Aliran Sungai Pekapuran-Banjarmasin The Pattern of Household Waste Management in Pekapuran River-Banjarmasin', 1 (2).

Riyanto, A. dan B. (2013) Kapita Selekta Kuesioner Pengetahuan dan Sikap dalam Penelitian Kesehatan. Jakarta: Salemba Medika.

Saputri, L. E., Fauzan, A. and Mahmudah (2020) 'Hubungan Karakteristik, Pengetahuan Dan Sikap Ibu Dalam Meminimalisasi Sampah Plastik Dengan Upaya 3R (Reuse, Reduce, Recycle) Desa Mandingin Kabupaten Hulu Sungai Tengah Tahun 2020', Hubungan Karakteristik, Pengetahuan Dan Sikap Ibu Dalam Meminimalisasi Sampah Plastik Dengan Upaya 3R (Reuse, 
Volume I Tahun 2021 November 2021
E-ISSN: 2808-5361 http://e-journal.fkmumj.ac.id/
Proceeding The First Muhammadiyah InternasionalPublic Health and Medicine Conference

Reduce, Recycle) Desa Mandingin Kabupaten Hulu Sungai Tengah Tahun 2020, p. 13.

Sarwono, S. . (2014) Sosiologi Kesehatan. Yogyakarta: Universitas Gajah Mada Press.

Setyowati, R. and Mulasari, S. A. (2013) 'Pengetahuan dan Perilaku Ibu Rumah Tangga dalam Pengelolaan Sampah Plastik', Kesmas: National Public Health Journal, 7(12), p. 562. doi: 10.21109/kesmas.v7i12.331.

Simanjutak, L. D. (2010) Perilaku Penjual Makanan yang Menggunakan Plastik dan Styrofoam di Lingkungan Kampus Universitas Sumatera Utara Tahun 2010. Medan: Fakultas Kesehatan Masyarakat Universitas Sumatera Utara.

Sumbung, H. (2015) 'Hubungan Antara Pengetahuan Dan Sikap Dengan Tindakan Penjual Gorengan Di Kota Manado Dalam Mengurangi Penggunaan Kantong Plastik', Fkm.Unsrat.Ac.Id, pp. 18.

Syafey, I. (2019) Peran Motivasi dan Kebijakan pada Kinerja Persampahan. Sleman: CV Budi Utama.

Thomas, G. O. et al. (2019) 'The English Plastic Bag Charge Changed Behavior and Increased Support for Other Charges to Reduce Plastic Waste', Frontiers in Psychology, 10(FEB), pp. 1-12. doi: 10.3389/fpsyg.2019.00266.

Thompson, R. C. et al. (2009) 'Our Plastic Age’, pp. 1973-1976. doi: 10.1098/rstb.2009.0054.

Utami, A. M. yuni, Listina, F. and Novariana, N. (2020) 'Faktor-Faktor Yang Berhubungan Dengan Perilaku Mahasiswa Dalam Penggunaan Plastik Dan Styrofoam Untuk Pembungkus Makanan Di Fakultas Kesehatan Universitas Mitra Indonesia Tahun 2020', Jurnal Formil (Forum Ilmiah) Kesmas Respati, 5(2), p. 129. doi: 10.35842/formil.v5i2.326.

Utami, F. A., Firdaus, D. R. S. and Martha, L. P. (2020) 'Efektivitas Kampanye Program Bogor Tanpa Kantong Plastik Dalam Membangun Kepedulian Masyarakat Pada Lingkungan', Jurnal Penelitian Sosial Ilmu Komunikasi, 4(2), pp. 102-112.

Wagner, T. P. (2017) 'Reducing Single-Use Plastic Shopping Bags in the USA', Waste Management, 70, pp. 3-12. doi: 10.1016/j.wasman.2017.09.003.

Wright, S. L., Thompson, R. C. and Galloway, T. S. (2013) 'The Physical Impacts of Microplastics on Marine Organisms: A Review.', Environmental pollution (Barking, Essex: 1987), 178, pp. 483-492. doi: 10.1016/j.envpol.2013.02.031.

Yuliana, S. (2016) 'Kajian terhadap Kebijakan Kantong Plastik Berbayar Berdasarkan Analisis Perilaku Konsumen'.

Yulnelly (2012) ‘Pemanfaatan Plastik sebagai Kemasan Pangan’, Bina Widya, 23(3), pp. 135-140. 